\title{
Nadwrażliwość elektromagnetyczna w Polsce - badania ankietowe
}

Streszczenie. Celem projektu było rozpoznanie problemu nadwrażliwości elektromagnetycznej (EHS) w Polsce, zwłaszcza w kontekście stosowania komunikacji bezprzewodowej. Badania przeprowadzono z zastosowaniem ankiety.

Abstract. The aim of the project was to identify the electromagnetic hypersensitivity (EHS) problem in Poland, especially in the context of the wireless communication applications. The project was performed as a survey study. (The Influence of Electromagnetic Fields on the Human Health - Survey Studies).

Słowa kluczowe: pola elektromagnetyczne, nadwrażliwość elektromagnetyczna, EHS, badania ankietowe. Keywords: electromagnetic fields, electromagnetic hipersensitivity, EHS, survey studies.

\section{Wstęp}

Szybki postęp technologiczny jaki obserwujemy wokół nas powoduje, że człowiek narażony jest na wciąż rosnącą ekspozycję na pole elektromagnetyczne z całego właściwie spektrum długości fal [1]. Promieniowanie elektromagnetyczne $\mathrm{z}$ zakresu wysokich energii, jak promieniowanie $\mathrm{X}$ gamma, posiadające zdolność jonizacji, ma bezsprzecznie niekorzystny wpływ na ludzi. W przypadku zakresu niejonizującego, związanego z częstotliwościami radiowymi i wyższymi $(1 \mathrm{~Hz}-300 \mathrm{GHz})(\mathrm{PEM})$, uznane są efekty oddziaływania na organizmy żywe w przypadku pól o wysokim natężeniu składowej elektrycznej (tzw. efekty termiczne). W przypadku niskich natężeń i gęstości mocy, z jakimi mamy do czynienia na co dzień w środowisku, niekorzystny wpływ na zdrowie nie został potwierdzony [25]. Określenie parametrów pola stanowiącego granicę pomiędzy oddziaływaniami termicznymi i nietermicznymi może stanowić podstawę do zdefiniowania norm zapewniających bezpieczne, w kontekście narażenia na ekspozycję na PEM, użytkowanie urządzeń [6].

Często postuluje się ostrożność we wprowadzaniu nowych technologii opartych o zastosowanie PEM dowodząc, że mogą one oddziaływać na żywe organizmy na skutek nieznanych mechanizmów, występujących przy gęstościach mocy nie wywołujących efektów termicznych - tzw. Oddziaływania nietermiczne. Badania mające na celu potwierzenie tego typu oddziaływań i wyjaśnienie ich mechanizmów nie przyniosły do tej wiarygodnych rezultatów [3-5]. Możliwości występowania negatywnych skutków dla niskich natężeń PEM nie można jednoznacznie wykluczyć, gdy równocześnie wykorzystuje się je do celów terapeutycznych [7], albo dowodzi korzystnego ich wpływu [8].

Ostatnio spore zainteresowanie i szczególnie wiele kontrowersji budzi problem szkodliwości PEM z zakresów częstotliwości stosowanych w telekomunikacji, a więc częstotliwości radiowych rzędu kilku i kilkunastu $\mathrm{GHz}$. Ma to związek z planami wprowadzenia komunikacji piątej generacji (5G), a w Polsce z pracami nad "megaustawą telekomunikacyjna”" nazywana potocznie „ustawą 5G” i z wprowadzeniem tych uregulowań [1].

Opisywany problem jest częścią większego projektu, związanego $z$ badaniami nad wpływem PEM na zdrowie ludzkie. Badania wiedzy społeczeństwa na ten temat nie były dotychczas prowadzone w Polsce, a według wiedzy autorów nie były również prowadzone badania nad problemem elektrowrażliwości elektromagnetycznej (electromagnetic hipersensitivity - EHS). Nie wiadomo więc, czy duże zainteresowanie mediów i świata polityki, jak również kontrowersje związane $z$ w/w problemami, znajduja pokrycie w obawach ogółu społeczeństwa, czy są w sposób sztuczny generowane i podnoszone.
Szczególny nacisk w niniejszej pracy został położony na rozpoznanie problemu EHS w naszym kraju. Termin ten pojawia się coraz częściej w świadomości społecznej i wiąże się $z$ dolegliwościami zgłaszanymi przez coraz większą liczbę osób, a wiązanymi z oddziaływaniem różnego rodzaju urządzeń elektrycznych, elektronicznych i, zwłaszcza, telekomunikacyjnych [9]. EHS zaliczane jest do grupy schorzeń idiopatycznych, czyli takich, których etiologia nie jest znana. W anglojęzycznej literaturze EHS funkcjonuje jako „idiopathic environmental intolerance attributed to electromagnetic fields (IEIEMF), co można przetłumaczyć, jako „idiopatyczna nietolerancja wywoływana czynnikami środowiskowymi przypisywana polom elektromagnetycznym" [10-11].

Objawy związane z EHS są bardzo liczne i w większości subiektywne, a więc niezwykle trudne do oceny i badania. Sprawia to, że EHS budzi spore kontrowersje w świecie naukowym i medycznym. Uznawana przez część świata naukowego, przez część traktowana jest jako wynik działania efektu odwróconego placebo (czyli nocebo) [12].

Niektóre badania szacują liczebność osób cierpiących z powodu EHS w badanych populacjach na kilka, albo nawet kilkadziesiąt procent [13-14].

\section{Materiał i metody}

Przeprowadzono ankietę mającą na celu zbadanie wiedzy na temat oddziaływania różnego rodzaju urządzeń codziennego użytku, a w szczególności urządzeń telekomunikacyjnych na organizm człowieka. Ankieta zawierała 32 pytania. Część pytań zawartych w ankiecie miała na celu określenie stanu zdrowia badanych na poziomie oceny subiektywnej, ale też pytano o zdiagnozowane i przebyte schorzenia i stosowane w związku z tym leki. Wiedza na temat subiektywnie i obiektywnie ocenianego stanu zdrowia została skonfrontowana $\mathrm{z}$ wynikami uzyskanymi przy pomocy kolejnej grupy pytań dotyczącej rodzaju i intensywności stosowania urządzeń, stanowiących potencjalne źródła ekspozycji na PEM.

Ankietę przeprowadzono w Internecie oraz - zważywszy na specyfikę EHS - w formie tradycyjnej (papierowej), wypełnianej osobiście. Pierwszym etapem badań była akcja informacyjna przeprowadzona przy pomocy środków masowego przekazu i mediów społecznościowych. Badania przeprowadzono w okresie od września do grudnia 2018 r.

Analizę statystyczną przeprowadzono z zastosowaniem programu Statgraphix Centurion XVIII. W przypadku zmiennych parametrycznych stosowano test Chi-Kwadrat do oceny istotności statystycznej badanych zależności. W przypadku zmiennych nieparametrycznych stosowano metodę ANOVA. 


\section{Wyniki i dyskusja}

Ankietę wypełniło łącznie 2884 osoby, z czego 1028 osób wypełniło ją w całości i tylko wyniki tych ankiet brane są pod uwagę w analizie danych. Zdecydowana większość wyników została pozyskana za pośrednictwem strony internetowej (1024), a jedynie 4 zostały wypełnione w formie tradycyjnej. 59\% ankietowanych stanowiły kobiety. Średnia wieku ankietowanych wynosiła $34 \pm 14$ lat (mediana 30 lat). Najmłodszy ankietowany miał 7 lat, a najstarszy 88.

Osoby biorące udział w badaniu zostały podzielone na dwie grupy: grupę osób, które można rozpatrywać pod kątem obciążenia EHS (ozn. EHS+) (408 osób) i takie, które nie wiążą oddziaływania PEM ze swoim samopoczuciem (EHS-) (468 osób). Klasyfikacja taka została przeprowadzona na podstawie dwóch pytań. Za EHS+ uznano osoby, które odpowiedziały pozytywnie na pytanie: „Czy urządzenia elektryczne / elektroniczne / telekomunikacyjne wpływają niekorzystanie na Pani/Pana samopoczucie?”, oraz wybrały odpowiedź „Wpływa” w pytaniu sformułowanym następująco: „Jeśli Pani/Pana zdaniem urządzenia elektryczne / elektroniczne / telekomunikacyjne wpływają niekorzystnie na Pani/Pana stan zdrowia, to proszę sprecyzować jakie urządzenia powodują u Pani/Pana pogorszenie samopoczucia. Proszę wybrać jedną z poniższych odpowiedzi, a następnie wypisać wszystkie takie urządzenia. (np. kuchenka mikrofalowa, kuchenka indukcyjna, (...))

\section{O Nie wpływa}

O Wpływa".

Warunkiem koniecznym uznania badanego za EHS+ było też wskazanie przynajmniej jednego urządzenia, którego oddziaływanie pogarsza jego samopoczucie.

Powstaje pytanie, czy na podstawie porównania liczebności EHS+ i EHS- można oszacować odsetek osób cierpiących na EHS. Należy tutaj zwrócić uwagę na wadę przeprowadzonego badania, jaką jest $z$ pewnością niereprezentatywność badanej grupy. Ankietowani nie byli dobierani w sposób losowy, a brali w niej udział z własnej woli, na podstawie własnej motywacji i decyzji. Udział w ankiecie $\mathrm{z}$ całą pewnością chętniej brały udział osoby zainteresowane tematem, a więc wydaje się, że były to częściej osoby, które mogą wiązać pogorszenie samopoczucia z PEM. Ponadto, ponieważ ankietę przeprowadzono głównie $\mathrm{w}$ Internecie, nie zostały nią objęte osoby, które z tego rodzaju medium nie korzystają. Gdyby jednak uznać grupę za reprezentatywną, można określić jedynie górną granicę odsetka osób elektrowrażliwych. Wyniosłaby ona 40\% (408/1028).

Metody szacowania zasięgu akcji promocyjnej pozwoliły oszacować liczbę osób, które miały dostęp do informacji o prowadzonym badaniu na około 37.5 tys. Gdyby liczbe EHS+ odnieść do tej populacji, to można oszacować dolną granicę odsetka osób elektrowrażliwych na $1.2 \%$ (zakładając, że wszyscy elektrowrażliwi zainteresowali się tematem i wypełnili ankietę).

Dalsza analiza danych uzyskanych w badaniu miała na celu określenie różnic pomiędzy grupą EHS+ i EHS-.

Jednym z aspektów projektu było sprawdzenie, czy osoby, które uznają się za EHS+ mogą być diagnozowane w kierunku fibromialgii. Fibromialgia, to zespół chorobowy charakteryzujący się uogólnionym bólem w układzie ruchu, któremu towarzyszy uczucie przewlekłego zmęczenia, wrażenie sztywności oraz sen niepowodujący poczucia odpoczynku. Jest to schorzenie idiopatyczne, charakteryzujące się całym szeregiem objawów niespecyficznych, subiektywnych i trudnych w ocenie, tak samo jak EHS. Objawy EHS i fibromialgii są podobne [15]. W ankiecie zadano cztery pytania, które stosuje się jako kryterium przesiewowe w przypadku podejrzenia o fibromialgię [16]:

„1. Czy u Pani/Pana występują zaburzenia snu - trudność w zasypianiu, bezsenność czy wybudzanie się w nocy?

2. Czy rano po przebudzeniu czuje się Pani/Pan zmęczona/y i niewypoczęta/y?

3. Czy w ciągu dnia jest Pani/Pan zmęczona/y co utrudnia pracę i obowiązki domowe?

4. Czy występuje u Pani/Pana wędrujący ból w wielu miejscach ciała, tj. rąk, nóg, klatki piersiowej i pleców, który trwa od ponad 3 miesiące?"

W przypadku, gdy pacjent odpowiada pozytywnie na dwa z w/w pytań, można brać pod uwagę rozszerzoną diagnostykę $w$ kierunku fibromialgii.

Średnia liczba objawów fibromialgii w grupach EHS+ i EHS- została przedstawiona w Tabeli 1. Test chi-kwadrat potwierdził statystycznie istotną różnicę pomiędzy obydwoma grupami.

Tabela 1. Średnia liczba zgłaszanych objawów charakterystycznych dla fibromialgii w grupach osób uznających się za elektrowrażliwe (EHS+) i takich, które nie uznaja się za elektrowrażliwe.

\begin{tabular}{|c|c|c|}
\cline { 2 - 3 } \multicolumn{1}{c|}{} & EHS+ & EHS- \\
\hline Liczba objawów fibromialgii & $2.5 \pm 1.1$ & $1.4 \pm 1.0$ \\
\hline
\end{tabular}

Osoby ankietowane miały możliwość podania informacji o swoim miejscu zamieszkania i pracy/nauki wybierając jeden z dwóch sposobów: poprzez wybór lokalizacji na mapie, albo przez podanie kodu pocztowego. $\mathrm{Na}$ tej podstawie scharakteryzowano grupę osób badanych pod względem miejsca zamieszkania. W opracowaniu danych brano pod uwagę lokalizację geograficzną, jak i klasyfikację miejsca zamieszkania/pracy/nauki odróżniając lokalizację wielkomiejską oraz pozamiejską. Nie wszyscy badani określili swoje miejsce zamieszkania/pracy/nauki, ale brak tej informacji nie wykluczał wyników z analizy.

Większość ankietowanych stanowili mieszkańcy Małopolski (823 osoby), z których z kolei większość zamieszkuje stolicę województwa - Kraków (663 osoby).

Pod względem miejsca zamieszkania oraz pracy/nauki podzielono ankietowanych na cztery grupy zakładając, że przebywanie $w$ mieście wiąże się $z$ większą ekspozycją na PEM niż przebywanie w obszarach pozamiejskich i że w miejscu zamieszkania przebywa się dłużej w ciągu doby niż w miejscu pracy/nauki [17]. Stąd osoby badane można podzielić na 4 kategorie pod względem narażenia na ekspozycję na PEM: wysokie (Exp_H), średnie-wyższe (Exp_MH), średnie-niższe (Exp_ML) i niskie (Exp_L).

Tabela 2. Podział ankietowanych wg miejsca zamieszkania/pracy/nauki odzwierciedlający narażenie na ekspozycję na PEM.

\begin{tabular}{|l|c|c|}
\cline { 2 - 3 } \multicolumn{1}{l|}{} & Ozn. & $\begin{array}{c}\text { Liczba } \\
\text { osób }\end{array}$ \\
\hline $\begin{array}{l}\text { Miejsce pracy/nauki i zamieszkania w } \\
\text { mieście }\end{array}$ & Exp_H & 656 \\
\hline $\begin{array}{l}\text { Miejsce pracy/nauki poza miastem, } \\
\text { miejsce zamieszkania w mieście }\end{array}$ & Exp_MH & 123 \\
\hline $\begin{array}{l}\text { Miejsce pracy/nauki w mieście, miejsce } \\
\text { zamieszkania poza miastem }\end{array}$ & Exp_ML & 109 \\
\hline $\begin{array}{l}\text { Miejsce pracy/nauki i zamieszkania poza } \\
\text { miastem }\end{array}$ & Exp_L & 140 \\
\hline
\end{tabular}

Analiza statystyczna nie wykazała istotnej statystycznie zależności pomiędzy klasyfikacją do jednej z czterech powyższych kategorii narażenia na ekspozycję, a częstotliwością wystąpienia EHS.

Osoby badane zostały poproszone o oszacowanie odległości ich miejsca pracy/nauki oraz zamieszkania do najbliższej stacji bazowej telefonii komórkowej. Analiza 
statystyczna również w tym wypadku nie stwierdza żadnych korelacji.

Stwierdzono natomiast istnienie istotnych statystycznie zależności pomiędzy płcią oraz wiekiem i przynależnością do EHS+. Okazuje się, że częściej jako elektrowrażliwe można uznać kobiety i osoby starsze.

Do ciekawych wniosków prowadzić może analiza stanu zdrowia badanych w kontekście EHS. W ankiecie zadano pytania pozwalające wnioskować o faktycznym stanie zdrowia badanych i o ich subiektywnej ocenie tego stanu zdrowia. Poproszono, aby ankietowany ocenił stan swojego zdrowia w skali 0-5 (gdzie 0 oznacza bardzo zły, a 5 oznacza bardzo dobry). Zadano również pytanie o choroby przewlekłe, na które cierpią ankietowani i o przebyte w przeszłości poważne schorzenia, albo zabiegi operacyjne. Problem chorób, na które cierpia ankietowani badano przy pomocy dwóch pytań. Jedno $z$ nich skonstruowano jako pytanie zamknięte, w którym badany mógł wybrać dowolna liczbę schorzeń z gotowej listy. Drugie pytanie było pytaniem otwartym, w którym ankietowany sam określał swoje dolegliwości. Następnie badano, czy istnieje zależność pomiędzy przynależnością do EHS+, a średnią liczbą schorzeń wskazywanych przez ankietowanych w pytaniu zamkniętym i w pytaniu otwartym. Analizowano również pod tym kątem liczbę przebytych w przeszłości poważnych chorób i zabiegów operacyjnych, jak również subiektywną ocenę samopoczucia. Wyniki tych analiz przedstawia Tabela 3.

Tabela 3. Wyniki analizy stanu zdrowia osób elektrowrażliwych (EHS+), oceniana przy pomocy subiektywnych i obiektywnych kryteriów, w stosunku do tych osób, które nie określają się jako elektrowrażliwe (EHS-). Dla parametrów zaznaczonych pogrubieniem stwierdzono istotną statystycznie różnicę, dla pozostałych nie stwierdzono takiej zależności.

\begin{tabular}{|l|c|c|}
\cline { 2 - 3 } \multicolumn{1}{c|}{} & EHS+ & EHS- \\
\hline $\begin{array}{l}\text { Stan zdrowia określany przez } \\
\text { badanego w skali } 0-5 \\
\text { (0-bardzo zły, } 5-\text { bardzo dobry) }\end{array}$ & $\mathbf{3 . 7 \pm 0 . 9}$ & $\mathbf{4 . 1 \pm 0 . 8}$ \\
\hline $\begin{array}{l}\text { Liczba chorób przewlekłych, na które } \\
\text { cierpi badany }\end{array}$ & 0.38 & 0.35 \\
\hline $\begin{array}{l}\text { Liczba schorzeń z listy zawartej w } \\
\text { pytaniu zamkniętym. }\end{array}$ & 0.53 & 0.49 \\
\hline $\begin{array}{l}\text { Liczba przebytych poważnych chorób } \\
\text { i zabiegów operacyjnych w } \\
\text { przeszłości }\end{array}$ & 0.36 & 0.32 \\
\hline
\end{tabular}

Tabela 4. Średnia liczba urządzeń AGD i urządzeń telekomunikacyjnych wskazywanych przez ankietowanych jako te, z których korzystaja na co dzień najczęściej. Pogrubieniem zaznaczono tę kategorię, dla której stwierdzono istotną statystycznie różnicę pomiędzy osobami elektrowrażliwymi (EHS+) i nie uważającymi się za elektrowrażliwe (EHS-).

\begin{tabular}{|l|c|c|}
\cline { 2 - 3 } \multicolumn{1}{c|}{} & EHS+ & EHS- \\
\hline Urządzenia AGD & $\mathbf{7 . 0 \pm 3 . 0}$ & $\mathbf{7 . 5} \pm \mathbf{3 . 0}$ \\
\hline Urządzenia telekomunikacyjne & $2.0 \pm 0.9$ & $2.0 \pm 0.8$ \\
\hline
\end{tabular}

Z tabeli wynika, że EHS+ określają swój ogólny stan zdrowia na gorszy i wykazują nieco więcej problemów zdrowotnych niż EHS-, ale różnica istotna statystycznie dotyczy tylko subiektywnej oceny, a nie parametrów, które w sposób bardziej obiektywny opisują stan zdrowia badanych.

Kolejnym pytaniem zadanym w ankiecie było pytanie, w którym starano się określić, czy osoby elektrowrażliwe unikają urządzeń elektrycznych i telekomunikacyjnych, w szczególności telefonów komórkowych, które przez wiele środowisk uznawane sa za największe obciążenie dla osób elektrowrażliwych. Ankietowani mogli w pytaniu zamkniętym wskazać dowolną liczbę urządzeń $z$ listy 21, z których korzystają na co dzień najczęściej. Urządzenia te do dalszej analizy zostały podzielone na urządzenia AGD (np. żelazko, czajnik elektryczny, lodówka, itp.), oraz urządzenia telekomunikacyjne (smartfon, router WiFi, telefon bezprzewodowy itp.). Określono średnią liczbę urządzeń stosowanych na co dzień przez grupę EHS+ i EHS-. Wyniki pokazano w Tabeli 4.

Powyższe dane sugerują, że osoby EHS+ bardziej obawiają się urządzeń AGD codziennego użytku, ale z nowoczesnych urządzeń telekomunikacyjnych korzystają równie chętnie jak osoby z grupy EHS-.Biorąc pod uwagę obydwie obserwacje można wysnuć wniosek, że przynależność do grupy EHS+ nie jest spowodowana na przykład niższym statusem społecznym, czy też niechęcią starszych ludzi do korzystania z urządzeń AGD, skoro równocześnie chętnie korzystają z urządzeń telekomunikacyjnych.

Tabela 5. Sposób wykorzystania telefonu komórkowego przez osoby elektrowrażliwe (EHS+) i nie uważające się za elektrowrażliwe. Pogrubieniem zaznaczono te kategorie, dla których zaobserwowano różnice istotne statystycznie.

\begin{tabular}{|l|c|c|}
\cline { 2 - 3 } & EHS+ & EHS- \\
\hline Rozmowy głosowe [\%] & $\mathbf{2 9 \pm \mathbf { 2 2 }}$ & $\mathbf{2 3} \pm \mathbf{2 1}$ \\
\hline SMS/MMS [\%] & $19 \pm 17$ & $17 \pm 17$ \\
\hline Internet [\%] & $\mathbf{5 2 \pm \mathbf { 2 3 }}$ & $\mathbf{6 0 \pm 2 3}$ \\
\hline Inne zastosowania [\%] & $14 \pm 15$ & $15 \pm 16$ \\
\hline $\begin{array}{l}\text { Liczba rozmów dłuższych niż 5 minut w } \\
\text { ciągu doby }\end{array}$ & $9 \pm 14$ & $8 \pm 17$ \\
\hline
\end{tabular}

Tabela 6. Wyniki odpowiedzi na pytanie, czy urządzenia wpływają korzystnie, czy nie korzystnie na zdrowie ludzi. Pogrubieniem zaznaczono odpowiedzi, w których stwierdzono istotnie statystyczną różnicę pomiędzy osobami elektrowrażliwymi (EHS+), a tymi które za takie się nie uważają (EHS-)

\begin{tabular}{|l|c|c|c|}
\cline { 2 - 4 } \multicolumn{1}{c|}{} & Ogół [\%] & EHS+[\%] & EHS-[\%] \\
\hline Wpływają niekorzystnie & 62.6 & $\mathbf{9 0 . 9}$ & $\mathbf{3 6 . 1}$ \\
\hline Wpływają korzystnie & 0.8 & 0.5 & 0.6 \\
\hline Nie wiem & 22.6 & $\mathbf{8 . 1}$ & $\mathbf{3 5 . 7}$ \\
\hline Nie wpływają & 14.0 & $\mathbf{0 . 5}$ & $\mathbf{2 7 . 6}$ \\
\hline
\end{tabular}

Tabela 7. Czynniki fizyczne związane z działaniem urządzeń codziennego użytku, które zdaniem ankietowanych wpływają niekorzystnie na zdrowie. W tabeli podano liczbę osób, które wybrały daną odpowiedź.

\begin{tabular}{|l|c|c|c|}
\cline { 2 - 4 } \multicolumn{1}{c|}{} & Ogółem & EHS + & EHS- \\
\hline Nie wpływa & 88 & 4 & 81 \\
\hline Nie wiem & 328 & 105 & 165 \\
\hline Promieniowanie jonizujące & 217 & 101 & 86 \\
\hline Promieniowanie rentgenowskie & 256 & 107 & 110 \\
\hline Promieniowanie gamma & 158 & 68 & 72 \\
\hline Promieniowanie ultrafioletowe & 186 & 89 & 63 \\
\hline Promieniowanie podczerwone & 118 & 66 & 32 \\
\hline Promieniowanie świetlne & 149 & 88 & 37 \\
\hline Fale radiowe niskich częst. & 170 & 94 & 49 \\
\hline Fale radiowe wysokich częst. & 263 & 148 & 79 \\
\hline Mikrofale & 317 & 171 & 101 \\
\hline Infradźwięki & 149 & 76 & 51 \\
\hline Fale akustyczne & 142 & 69 & 54 \\
\hline Fale ultradźwiękowe & 162 & 91 & 46 \\
\hline Inne rodzaje prom. & 25 & 19 & 3 \\
\hline
\end{tabular}

Potwierdza to również analiza pytań związana z wykorzystaniem telefonów komórkowych. Ankietowani zostali poproszeni o określenie stopnia wykorzystania telefonu komórkowego do różnych celów. Mieli oszacować w ilu procentach stosują go do prowadzenia rozmów głosowych, wysyłania i odbierania SMSów i MMSów, korzystania z Internetu i do innych celów. Padło również pytanie liczbę rozmów telefonicznych trwających dłużej niż 5 minut w ciągu doby. Zaobserwowano różnice statystyczne pomiędzy EHS+ i EHS- w przypadku rozmów głosowych i korzystania z Internetu. Okazuje się, że osoby zaliczone do grupy EHS+ chętniej korzystają z rozmów głosowych, natomiast rzadziej używają telefonu do komunikacji $z$ 
Internetem (Tabela 5). Efekt ten może być związany z obserwowana statystycznie istotna zależnościa pomiędzy przynależnością do EHS+, a wiekiem. Starsze osoby mogą być bardziej przyzwyczajone do tradycyjnej formy wykorzystania telefonu, niż do korzystania z Internetu.

Jednym z celów przeprowadzonych badań, na który położono mniejszy nacisk w niniejszym opracowaniu, jest stan wiedzy społeczeństwa na temat potencjalnych zagrożeń ze strony ekspozycji na PEM. W pierwszej kolejności zadano pytanie, czy według wiedzy badanego urządzenia elektryczne, / elektroniczne / telekomunikacyjne wpływają na zdrowie ludzi i czy wpływają korzystnie, czy nie (Tabela 6). Osoby z grupy EHS+ zdecydowanie uważają, że oddziaływanie tego rodzaju urządzeń ma miejsce i jest niekorzystne, co nie jest zaskakujące, skoro czują się elektrowrażliwe. Równocześnie osoby takie znacznie mnie chętnie przyznają się do swoje niewiedzy na ten temat w stosunku do grupy EHS-.

Pytaniem pozwalającym na realną ocenę wiedzy na temat oddziaływań na ludzkie zdrowie było następujące pytanie: „Uważa się, że oddziaływanie urządzeń elektrycznych / elektronicznych / telekomunikacyjnych stosowanych w życiu codziennym na człowieka wiąże sie z emisją fal absorbowanych następnie przez jego organizm. Jakiego rodzaju promieniowanie emitowane przez tego typu urządzenia wg Pani/Pana wiedzy wpływa niekorzystanie na Pani/Pana samopoczucie? (można wybrać kilka możliwości): nie wpływa, nie wiem, promieniowanie jonizujące, promieniowanie rentgenowskie, promieniowanie gamma, promieniowanie ultrafioletowe, promieniowanie podczerwone, promieniowanie świetlne, fale radiowe niskich częstotliwości, fale radiowe wysokich częstotliwości, mikrofale, infradźwięki, fale akustyczne, fale ultradźwiękowe, inne (proszę napisać jakie)" (Wyniki przedstawiono w Tabeli 6).

Wskazanie promieniowania jonizującego, X, gamma ultrafioletu zastosowano jako wskaźnik niewiedzy w dalszej analizie, gdyż urządzenia codziennego użytku poza przypadkami marginalnymi nie emitują tego rodzaju promieniowania. Zliczono liczbę tych odpowiedzi porównano ją w populacjach EHS+ i EHS- (Tabela 8). Różnica pomiędzy grupą EHS+ i EHS- w średniej liczbie błędnie wybranych czynników fizycznych jest istotna statystycznie.

Tabela 8. Liczba błędnie wskazanych czynników fizycznych generowanych przez urządzenia codziennego użytku. Różnica pomiędzy osobami eletrowrażliwymi (EHS+), a nieelektrowrażliwymi (EHS-) jest istotna statystycznie.

\begin{tabular}{|l|c|c|}
\cline { 2 - 3 } \multicolumn{1}{c|}{} & EHS+ & EHS- \\
\hline Liczba błędnie wskazanych czynników & $\mathbf{0 . 9 \pm 1 . 2}$ & $\mathbf{0 . 7 \pm \mathbf { 1 . 2 }}$ \\
\hline
\end{tabular}

Analiza wyników zawartych w Tabelach 6,7 i 8 wydaje się sugerować, że osoby uznające się za EHS+ przeceniaja stan swojej wiedzy na temat oddziaływania urządzeń technicznych na zdrowie, przy czym realny stan ich wiedzy na ten temat jest istotnie niższy niż w przypadku grupy EHS-. Obserwacja ta nieco przypomina efekt DunningaKrugera, który polega na tym, że osoby o niższym poziomie wiedzy specjalistycznej mają skłonność do przeceniania swoich umiejętności, podczas, gdy specjaliści w dane dziedzinie zwykle zaniżają swoją ocenę [18].

Warto przy okazji zwrócić uwagę, że zaskakująco duża liczba ankietowanych kojarzy mikrofale (31\%) i fale radiowe wysokich częstotliwości (26\%) z działaniem urządzeń codziennego użytku, co przeczy dość powszechnemu przekonaniu, że większość społeczeństwa nie wie w jaki sposób działają urządzenia stosowane w nowoczesnej telekomunikacji (Tabela 7).
Uzyskane w ankietach wyniki pozwoliły ustalić ranking najczęściej zgłaszanych dolegliwości, które są wiązane $z$ oddziaływaniem urządzeń elektrycznych / elektronicznych / telekomunikacyjnych. Wyniki te przedstawiono w Tabeli 9.

Tabela 9. Objawy zgłaszane przez osoby elektrowrażliwe, które wiązane są $\mathrm{z}$ oddziaływaniem urządzeń elektrycznych / elektronicznych / telekomunikacyjnych. Tabela przedstawia liczbę osób, które wskazały wybraną dolegliwość i liczbę tą odniesioną do liczny wszystkich osób, które możemy uznać za elektrowrażliwe (408).

\begin{tabular}{|c|l|r|r|}
\cline { 3 - 4 } \multicolumn{2}{l|}{} & Liczba & $\%$ \\
\hline 1 & Zmęczenie & 326 & 79,9 \\
\hline 3 & Bó głowy & 303 & 74,3 \\
\hline 3 & Ból oczu & 278 & 68,1 \\
\hline 4 & Rozdrażnienie & 269 & 65,9 \\
\hline 5 & Trudności z koncentracją & 261 & 64,0 \\
\hline 6 & Problemy z zasypianiem & 166 & 40,7 \\
\hline 7 & Niepokój & 151 & 37,0 \\
\hline 8 & Senność & 130 & 31,9 \\
\hline 9 & Wybudzenia nocne & 114 & 27,9 \\
\hline 10 & Kłopoty z uczeniem się & 98 & 24,0 \\
\hline 11 & Łzawienie & 88 & 21,6 \\
\hline 12 & Bezsenność & 77 & 18,9 \\
\hline 13 & Ból stawów & 74 & 18,1 \\
\hline 14 & Nieprzyjemne wrażenia słuchowe & 74 & 18,1 \\
\hline 15 & Nieprzyjemne wrażenia wzrokowe & 63 & 15,4 \\
\hline 16 & Trudności w wysławianiu się & 58 & 14,2 \\
\hline 17 & Kołatanie serca & 58 & 14,2 \\
\hline 18 & Ból ucha & 46 & 11,3 \\
\hline 19 & Podwyższone ciśnienie & 41 & 10,0 \\
\hline 20 & Suchość w ustach & 39 & 9,6 \\
\hline 21 & Podwyższone tętno & 38 & 9,3 \\
\hline 22 & Swędzenie & 35 & 8,6 \\
\hline 23 & Duszności & 26 & 6,4 \\
\hline 24 & Katar & 24 & 5,9 \\
\hline 25 & Zaczerwienienie skóry & 24 & 5,9 \\
\hline 26 & Arytmia & 23 & 5,6 \\
\hline 27 & Kaszel & 23 & 5,6 \\
\hline 28 & Chrypka & 23 & 5,6 \\
\hline 29 & Obniżone ciśnienie & 14 & 3,4 \\
\hline 30 & Wysypka & 10 & 2,5 \\
\hline 31 & Obrzęk & 8 & 2,0 \\
\hline 32 & Obniżone tętno & 4 & 1,0 \\
\hline & & & \\
\hline & & & \\
\hline
\end{tabular}

Tabela 10. Urządzenia wywołujące negatywne skutki zdrowotne u osób należących do grupy elektrowrażliwych. W tabeli podano liczbę osób zgłaszających poszczególne urządzenia i procent tych osób w odniesieniu do całkowitej liczby elektrowrażliwych (408).

\begin{tabular}{|c|l|c|c|}
\cline { 3 - 4 } \multicolumn{2}{l|}{} & Liczba & $\%$ \\
\hline 2 & Telefon komórkowy & 264 & 64.7 \\
\hline 3 & Kaptop & 156 & 38.2 \\
\hline 4 & Rouputer & 146 & 35.8 \\
\hline 5 & Odbiornik telewizyjny & 135 & 33.1 \\
\hline 6 & Kuchenka mikrofalowa & 132 & 32.4 \\
\hline 7 & Linie energet. wysokiego napięcia & 108 & 26.5 \\
\hline 8 & Stacje bazowe telefonii komórkowej & 81 & 19.9 \\
\hline 9 & Telefon & 65 & 15.9 \\
\hline 10 & Tablet & 40 & 9.8 \\
\hline 11 & Żarówka energooszczędna & 36 & 8.8 \\
\hline 12 & Linie energet. średniego napięcia & 31 & 7.6 \\
\hline 13 & Monitory / ekrany / wyświetlacze & 31 & 7.6 \\
\hline 14 & Linie energet. niskiego napięcia & 28 & 6.9 \\
\hline 15 & Kuchnia indukcyjna & 24 & 5.9 \\
\hline 16 & Telefon bezprzewodowy & 13 & 3.2 \\
\hline 17 & Żarówki LED & 10 & 2.5 \\
\hline
\end{tabular}

Warto zwrócić uwagę, że znaczna część wskazanych w powyższej tabeli objawów jest objawami subiektywnymi, a więc równocześnie niezmiernie trudnymi $w$ ilościowej i obiektywnej ocenie. W rankingu najczęściej zgłaszanych objawów pierwszy symptom, który można uznać za taki, który można oceniać ilościowo i obiektywnie, to łzawienie 
występujące dopiero na 11stej pozycji, które zgłaszane jest przez co piątą osobę należącą do grupy EHS+.

Przeprowadzona ankieta pozwala również na przedstawienie rankingu urządzeń, które u osób z grupy EHS+ powodują negatywne skutki zdrowotne. Lista urządzeń przedstawiona jest w Tabeli 10. Pytanie to było pytaniem otwartym, dlatego nieco trudności nastręczała klasyfikacja telefonów, gdyż w przypadku, gdy ankietowany wpisywał słowo „telefon”, nie było wiadomo, czy chodzi o telefon przewodowy, bezprzewodowy, czy komórkowy. Dlatego w Tabeli w osobnych pozycjach podano zliczenia dla sformułowania „telefon bezprzewodowy”, „telefon komórkowy” i „telefon”. Określenie „smartfon” zaliczono do kategorii „telefon komórkowy”.

Analiza powyższych wyników może prowadzić do kilku ciekawych wniosków. Najbardziej zaskakujący jest chyba taki, że większość badanych wiąże zdecydowanie częściej swoje symptomy z oddziaływaniem swoich własnych telefonów, niż stacji bazowych telefonii komórkowej (SBTK). Tym czasem powszechne przekonanie jest takie, że ludność odczuwa większy lęk przez SBTK, niż terminalami przenośnymi. Obserwacja ta może również sugerować, że wiedza społeczna na temat oddziaływania PEM z zakresu częstotliwości radiowych jest wyższa, niż się na ogół sądzi.

Z drugiej jednak strony wnioskowi takiemu przeczy fakt, że na wysokich pozycjach w rankingu są urządzenia, które nie są raczej źródłami PEM o dużych natężeniach $i$ gęstościach mocy, a których negatywne oddziaływanie na nasze samopoczucie raczej nie wynika $z$ działania PEM, ale z działania innych czynników. Znakomitym przykładem są tutaj laptopy.

\section{Wnioski}

Osoby określające się jako elektrowrażliwe mogą być diagnozowane również w kierunku fibormialgii, gdyż grupa EHS+ obserwuje u siebie więcej objawów charakterystycznych dla tego schorzenia niż grupa EHS- i różnica ta jest statystycznie znacząca (Tabela 1).

Postrzeganie się jako EHS+ nie zależy od stopnia narażenia na PEM. Nie wykazano bowiem zależności pomiędzy częstotliwością występowania EHS, a z miejscem zamieszkania / pracy / nauki w obszarach miejskich i pozamiejskich. Nie istnieje również taka zależność pomiędzy tą częstotliwością, a odległością od SBTK w miejscu zamieszkania oraz pracy/nauki.

Istnieje zależność pomiędzy częstotliwością określania się jako EHS+, a płcią i wiekiem. Częściej elektrowrażliwe są kobiety i zjawisko to występuje częściej u osób starszych. Obserwacja ta pokrywa się z doniesieniami literaturowymi.

Osoby elektrowrażliwe oceniają swój stan zdrowia na gorszy niż inne osoby, ale ocena parametrów opisujących stan zdrowia obiektywnie nie potwierdza istotnie gorszego stanu zdrowia.

Osoby elektrowrażliwe predestynują do posiadania wiedzy na temat zagrożeń związanych z oddziaływaniem PEM na zdrowie, ale ich realna wiedza jest niższa niż osób, które nie uważają się za elektrowrażliwe.

Objawy zgłaszane jako symptomy elektrowrażliwości są najczęściej subiektywne i trudne do ilościowej oceny.

Wbrew powszechnemu przekonaniu, że większość osób odczuwa większy lęk przez SBTK niż telefonami komórkowymi, te ostatnie czterokrotnie częściej są zgłaszane jako źródło symptomów zgłaszanych przez osoby elektrowrażliwe.

Należy zwrócić uwagę, na to, że ze względu na znaczący udział $w$ badaniu osób zamieszkujących rejon Małopolski wnioski dotyczące omawianych problemów w skali całego kraju mogą być ograniczone.
Autorzy: dr hab. Grzegorz Taton, Zakład Biofizyki, Katedra Fizjologii, Uniwersytet Jagielloński Collegium Medicum, ul. Św. Łazarza 16, 31-530 Kraków, e-mail: g.taton@uj.edu.pl; mgr Piotr Kuterba, j.w., E-mail: piotr.kuterba@uj.edu.pl; dr Bartosz Lisowski, j.w. e-mail: bartek.lisowski@uj.edu.pl; dr Tomasz Rok, j.w., e-mail: tomasz.rok@uj.edu.pl; prof. dr hab. Eugeniusz Rokita, j.w., e-mail: e.rokita@uj.edu.pl

\section{LITERATURA}

[1] Łamża Ł. (red.), Pole elektromagnetyczne a człowiek. O fizyce, biologii, medycynie, normach i sieci 5G, Warszawa, 2019.

[2] Kodera S., Gomez-Tames J., Hirata A.. Temperature elevation in the human brain and skin with thermoregulation during exposure to RF energy, Biomed Eng Online. BioMed Central, 17 (2018), 1, 1-17.

[3] Sheppard A.R., Swicord M.L., Balzano Q., Quantitative evaluations of mechanisms of radiofrequency interactions with biological molecules and processes, Health Phys, 95 (2008), 4, 365-96.

[4] Panagopoulos D.J., Johansson O., Carlo G.L., Polarization: A Key Difference between Man-made and Natural Electromagnetic Fields, in regard to Biological Activity, Sci Rep. Nature Publishing Group, 2015 (2015), 5, 14914.

[5] Gherardini L., Ciuti G., Tognarelli S., Cinti C., Searching for the perfect wave: The effect of radiofrequency electromagnetic fields on cells, Int J Mol Sci, 15 (2014), 4, 5366-87.

[6] Krawczyk A., Lada-Tondyra E., The Evolution of Electromagnetic Field Standards - case study of ICNIRP's Standards, Przegląd Elektrotechniczny, 87 (2011), 12B, 89-91.

[7] Krawczyk A., Miaskowski A., Lada-Tondyra E., Healing of orthopaedic diseases by means of electromagnetic field, Przegląd Elektrotechniczny, 86 (2010), 12, 72-74

[8] Mortazavi S.A.R., Tavakkoli-Golpayegani A., Haghani M., Mortazavi S.M.J., Looking at the other side of the coin: the search for possible biopositive cognitive effects of the exposure to $900 \mathrm{MHz}$ GSM mobile phone radiofrequency radiation, J Environ Heal Sci Eng, 12 (2014), 75.

[9] Carpenter D.O., The microwave syndrome or electrohypersensitivity: Historical background, Rev Environ Health, 30 (2015), 4, 217-22.

[10]Verrender A., Loughran S.P., Anderson V., Hillert L., Rubin G.J., Oftedal G., IEI-EMF provocation case studies: A novel approach to testing sensitive individuals, Bioelectromagnetics. 39 (2018), 2, 132-43.

[11]Eltiti S., Wallace D., Russo R., Fox E., Aggregated data from two double-blind base station provocation studies comparing individuals with idiopathic environmental intolerance with attribution to electromagnetic fields and controls, Bioelectromagnetics, 36 (2015) 2, 96-107.

[12] Verrender A., Loughran S.P., Dalecki A., Freudenstein F., Croft RJ. Can explicit suggestions about the harmfulness of EMF exposure exacerbate a nocebo response in healthy controls?, Environ Res, 166 (2018), 409-17.

[13] Gruber M.J., Palmquist E., Nordin S., Characteristics of perceived electromagnetic hypersensitivity in the general population, Scand J Psychol, 59 (2018), 4, 422-7.

[14] Slottje P., van Moorselaar I., van Strien R., Vermeulen R., Kromhout $H$., Huss A., Electromagnetic hypersensitivity (EHS) in occupational and primary health care: A nation-wide survey among general practitioners, occupational physicians and hygienists in the Netherlands, Int J Hyg Environ Health, 220 (2017), 2, 395-400.

[15] Savall A., Dieudonne M., De Lazzari M., Hassam R., Cathebras P., One or more functional somatic syndromes? Comparison of the health status of fibromyalgia and electrohypersensitive people, Rev Med Interne, 2019, w druku, https://doi.org/10.1016/j.revmed.2019.02.007.

[16] Gibson K.A., Castrejon I., Descallr J., Pincus T., Fibromyalgia Assessment Screening Tool (FAST): clues to fibromyalgia on a multidimensional health assessment questionnaire (MDHAQ) for routine care, J Rheumatol, 2019, doi: 10.3899/jrheum.190277.

[17] Sagar S.M., Adem B., Struchen S.P., Loughran S.P., Environment International, 114 (2018), 297-306.

[18] Kruger J., Dunning D, Unskilled and unaware of it: how difficulties in recognizing one's own incompetence lead to inflated self-assessments, Journal of Personality and Social Psychology, 77 (1999), 6, 1121-1134. 